\title{
VULNERABILITY ASSESSMENT TO CLIMATE-INDUCED HAZARDS OF THE MUNICIPALITY OF MASINLOC, ZAMBALES, PHILIPPINES
}

\author{
A. M. Paz-Alberto ${ }^{1, *}$, E. E. Camaso ${ }^{1}$, G. P. L. Abella ${ }^{1}$, C. H. E A. De Guzman ${ }^{1}$, C. R. Genaro ${ }^{1}$ and K. M. Mapanao ${ }^{1}$ \\ ${ }^{1}$ Institute for Climate Change and Environmental Management, Central Luzon State University, Science City of Muñoz, Nueva \\ Ecija, Philippines
}

Commission IV

KEY WORDS: Climate-Induced Hazards, Vulnerability Assessment, Exposure, Sensitivity, Adaptive Capacity

\begin{abstract}
:
The Philippines is surrounded by hundreds of kilometers of shorelines wherein communities are increasing and coastal development is emerging fast. Masinloc, Zambales is a coastal municipality wherein 11 out of 13 barangays are situated near the coast which are always affected by climate-induced hazards. The objectives of this study were to assess and validate the climate-induced hazards occurring in Masinloc and assessed the vulnerability of the coastal municipality to these various hazards. Detailed profiling was done to identify hazards of the study area. Vulnerability maps were generated and results revealed that flooding, storm surge and landslide were the most prominent hazards in the area. Results of the vulnerability assessment revealed that Masinloc was moderately vulnerable to storm surge and flooding due to low exposure and sensitivity to flooding and storm surge while its adaptive capacity was very high. Majority of settlements, agricultural lands and population are affected by these hazards. Priority programs to reduce the sensitivity and exposure to storm surge and flooding should be carried out.
\end{abstract}

\section{INTRODUCTION}

The Philippines is composed of hundreds of kilometers of shorelines wherein coastal communities are located and emerging fast. It is surrounded by large bodies of water namely the West Philippine Sea and Pacific Ocean which pose hazards or threats like storm surge, flooding and even rain-induced landslides. Coastal communities are dense and over-populated for the main reason that coastal resources are available that provide people livelihood. Hazards not only affect the coastal communities but also other ecosystems like agriculture. Approximately 60 percent of the Philippine population is residing or lives within the 832 coastal municipalities and 25 coastal cities (DENR et al. 1997). This means that a lot of coastal communities are in danger and vulnerable to these climate-induced hazards. Several studies show that climate change-induced hazards have significant impacts not only in coastal ecosystems but also in the communities within the ecosystem as well (Alberto et al, 2018; Badjeck et al, 2010; Faustino and Sales, 2009; and Paquit, et al. 2018). Measuring the vulnerability of these communities and ecosystems to climate change and hazards is very imperative. Studies shows that not only coastal ecosystems may be affected by climate change but also other agricultural ecosystems as well [6] [7] for coastal areas also has agricultural sectors. The country ranked $3^{\text {rd }}$ on the world risk index and was considered as one of the highly disaster-prone countries in the world (WRR, 2015). Masinloc, Zambales is a coastal municipality having 11 out of 13 barangays being located in the coast. Hence, this research was conducted to assess and validate climate-induced hazards in Masinloc, Zambales and to assess the vulnerability of this coastal municipality to these kinds of hazards.

\section{MATERIALS AND METHOD}

\subsection{Site Selection and Scoping}

Scoping was utilized in the study which used specific guidelines and gathered not only secondary data but primary data as well to cover both environmental and socio-economic factors. The following conditions were considered in identifying the study site: 1) coastal municipality; 2) presence of relevant climateinduced hazards; 3 ) availability of comprehensive land use plan or updated comprehensive land use plan; and 4) presence of the updated municipal agricultural profile.

\subsection{Vulnerability Assessment}

The vulnerability of the coastal sector of the municipality of Masinloc, Zambales was assessed in terms of how sensitive and exposed Masinloc, Zambales on natural hazards and how both the communities and ecosystems adapt to flooding, storm surge and rain-induced landslide using the checklist developed by Espaldon et al., (2016). Tables 1 and 2 present the categories and scale range used for sensitivity and exposure and adaptive capacity, respectively.

\begin{tabular}{|ccc|}
\hline \multicolumn{2}{|c}{ CATEGORIES } & SCALE RANGE \\
\hline \multirow{3}{*}{ Very Low } & VL1 & $0.20-0.25$ \\
& VL2 & $0.26-0.30$ \\
Low & L1 & $0.31-0.40$ \\
& L2 & $0.41-0.50$ \\
Moderate & M1 & $0.51-0.60$ \\
& M2 & $0.61-0.70$ \\
High & H1 & $0.71-0.80$ \\
& H2 & $0.81-0.90$ \\
Very High & VH1 & $0.91-0.95$ \\
& VH2 & $0.96-1.00$ \\
\hline
\end{tabular}

Table 1. Scale for sensitivity, exposure and vulnerability indices (Alberto et al., 2018) 


\begin{tabular}{|ccc|}
\hline \multicolumn{2}{|c}{ CATEGORIES } & SCALE RANGE \\
\hline Very Low & VL1 & $0.96-1.00$ \\
& VL2 & $0.91-0.95$ \\
Low & L1 & $0.81-0.90$ \\
& L2 & $0.71-0.80$ \\
Moderate & M1 & $0.61-0.70$ \\
& M2 & $0.51-0.60$ \\
High & H1 & $0.41-0.50$ \\
& H2 & $0.31-0.40$ \\
Very High & VH1 & $0.26-0.30$ \\
& VH2 & $0.20-0.25$ \\
\hline
\end{tabular}

Table 2. Scale for adaptive capacity (Alberto et al., 2018)

\section{RESULTS AND DISCUSSION}

\subsection{Vulnerability Assessment and Mapping}

The municipality of Masinloc is composed of 13 barangays which 11 of these are considered coastal communities. Based on the Comprehensive Land Use Plan of Masinloc (2018), there was an estimated 33,151.49 hectares comprising of 142.09 hectares coastal, 281.43 hectares of residential areas and $5,497.56$ hectares of agricultural lands. Results revealed that Municipality of Masinloc is subjected to flood, landslide, storm surge and tsunami and is vulnerable to these kinds of hazards.

\subsection{Flooding}

Results of the vulnerability assessment to flooding revealed that the municipality of Masinloc had an index score of (0.53) which is considered moderate as shown in Table 1. Figure 1 shows that most of the barangays are moderate vulnerability to flooding except for San Lorenzo, Tapuac and Collat which had low vulnerability to flooding. In terms of municipality's sensitivity (0.30) and exposure (0.20) to flooding, they were very low, while their adaptive capacity $(0.20)$ index score was very high. Moderate flooding in the area is defined to have some inundation of structures and roads near the river and creeks. The creeks/rivers that traverse the municipality influence flooding in the area. However, Masinloc has the equipment to adapt to flooding (rescue vehicles, dump trucks, radio communication throughout the municipality and life boats), availability of annual historical data to better identify the priority areas that may be affected during time of flooding and establishment of radio communication in every barangay for faster and efficient coordination and updating their flood maps is very significant and crucial in coping with the occurrence of flood. The condition and accessibility of infrastructure, accessibility of health care, human and social capital (the skills, knowledge, experience, and social cohesion of a community), and other institutional resources all contribute to the timeliness and effectiveness of adaptive capacity.

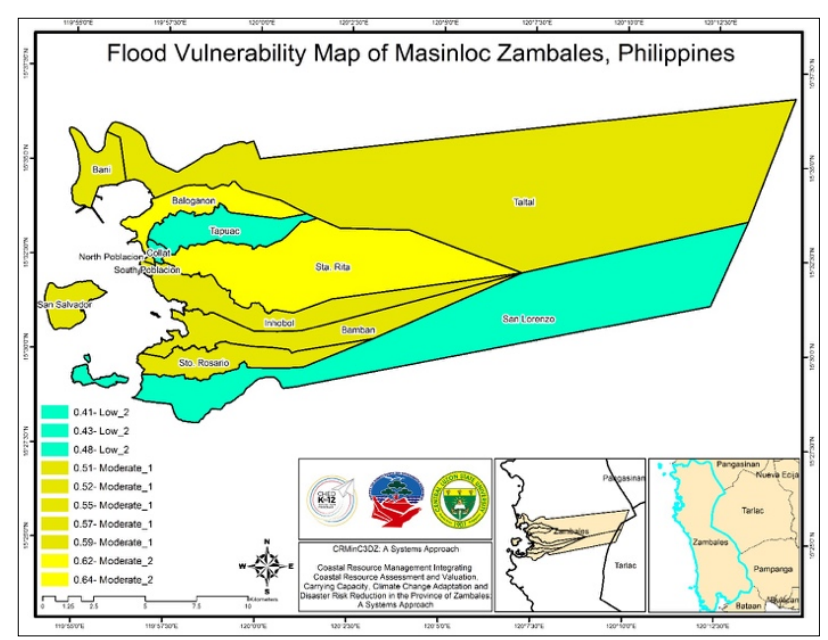

Figure 1. Flood vulnerability map of Masinloc, Zambales, Philippines

\subsection{Storm Surge}

Results of the storm surge vulnerability assessment in Masinloc, Zambales is shown in Figure 2. Overall, Masinloc had moderate vulnerability $(0.64)$ to storm surge. It had very low sensitivity $(0.26)$ to storm surge and very low exposure $(0.20)$ while its adaptive capacity again was very high $(0.20)$. Almost all barangays in Masinloc are coastal barangays in other words villages located near the coastal and low-lying areas are more vulnerable to storm surges. However, Masinloc also has disaster preparedness program and plan for this kind of hazard. The LGU of Masinloc also established a sea wall to reduce the effects of storm surge.

Barangay San Salvador had high vulnerability index score of (0.79) for Barangay San Salvador was highly sensitive and exposed to storm surge. It is an island barangay covering an area of 437.2 hectares. Natural buffers, like mangrove forest and sea grass, are not sufficient enough to protect them from storm surge. Small islands are generally considered highly vulnerable to climate change because they suffer from most common environmental problems due to their smallness, remoteness and exposure to natural hazards, though they contribute less to climate change (Scandura et al. 2018).

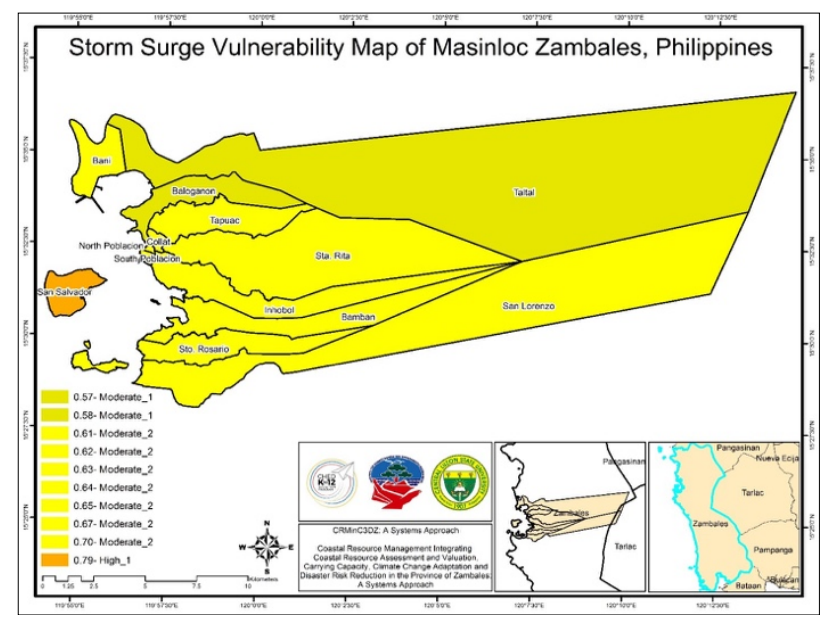

Figure 2. Storm surge vulnerability map of Masinloc, Zambales, Philippines 


\subsection{Landslide}

Figure 3 shows that the municipality of Masinloc had low vulnerability $(0.43)$ to landslide. Masinloc had very low sensitivity (0.12) and very low exposure (0.09) to landslide. However, the municipality had very high adaptive capacity $(0.22)$ to landslide.

Masinloc has low vulnerability to landslide because agricultural areas, houses and residents are very far from the mountains which are landslide prone areas. Moreover, no presence of construction/extraction activities and charcoal making were found in the forest of Masinloc and in fact, its disaster plans are well prepared and coordinated throughout the municipality.

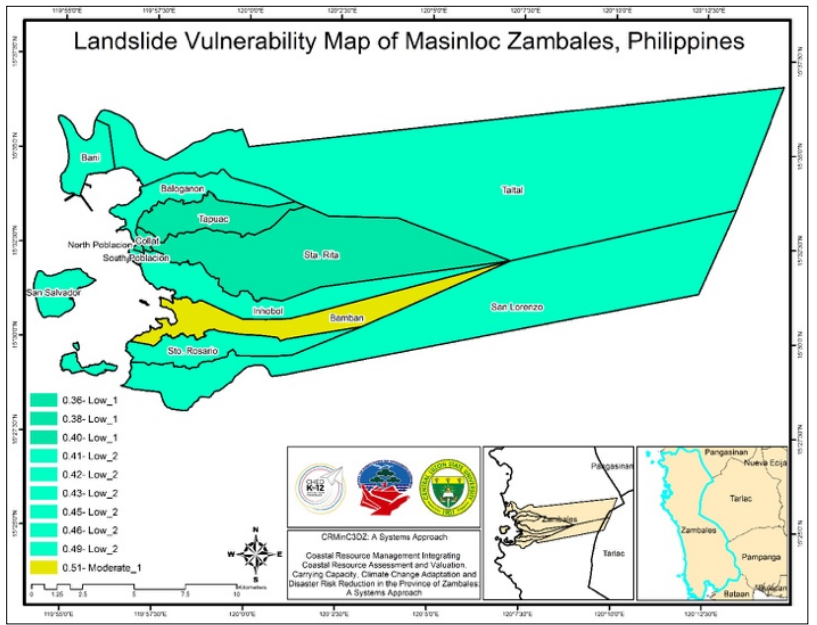

Figure 3. Landslide vulnerability map of Masinloc, Zambales, Philippines

\section{CONCLUSION}

Masinloc had moderate vulnerability to flooding and storm surge while low vulnerability to rain-induced landslide. Masinloc's vulnerability to these hazards remained low to moderate mainly because the municipality is prepared in terms manpower, coordination, and infrastructures to cope with these particular hazards. In addition, it also exerted an effort of improving its disaster preparedness plan to specifically identify the areas that are prone to different hazards. The municipality also established a stable communication in time of disaster to monitor and prevent the effects of hazards throughout the municipality.

\section{RECOMMENDATIONS}

In order to improve the results and analysis of this study, it is recommended that the results and findings of this study be validated with the stakeholders. It is also recommended that such studies be used in other local government units to determine specific localities for program prioritization.

\section{ACKNOWLEDGMENT}

The authors are grateful to our funding agency, Commission on Higher Education (CHED)-DARE-TO K12 Program for the trust and confidence especially in our abilities to come up with significant outputs and in the accomplishment of our objectives. Sincere gratitude also to LGUs and coastal communities in
Masinloc, Zambales for the support provided in conducting the study.

\section{REFERENCES}

Alberto, A.M.P., de Dios, M.J.J., Alberto, R.P. and De Guzman, C.H.E.A. (2018) Climate Change Impacts and Vulnerability Assessment of Selected Municipalities and Agroecosystems to Support Development of Resilient Communities and Livelihoods in Nueva Ecija, Philippines. American Journal of Climate Change, 7, 295-335. https://doi.org/10.4236/ajcc.2018.72019

Badjeck, M., Allison, E.H., Halls, A.S. and Dulvy, N.K. (2010) Impacts of Climate Change Variability and Change on FisheryBased Livelihoods. Marine Policy, 34, 375-383. https://doi.org/10.1016/j.marpol.2009.08.007

Espaldon M.V., H.G. Centeno and C. Tiburan Jr. (2016). Vulnerability Indicators. Handout

DENR-DILG-DA/BFAR-CRMP (Department of Environment and Natural Resources, Department of Interior and Local Government, Department of Agriculture - Bureau of Fisheries and Aquatic Resources, and the Coastal Resource Management Project). 1997. Legal and jurisdictional guidebook for coastal resource management in the Philippines. Coastal Resource Management Project, Cebu City, Philippines. 196 p.

Faustino M. Sales, Ramon. (2009). Vulnerability and adaptation of coastal communities to climate variability and sea-level rise: Their implications for integrated coastal management in Cavite City, Philippines. Ocean \& Coastal Management. 52. 395-404. 10.1016/j.ocecoaman.2009.04.007.

Parker L., Bourgoin C., Martinez-Valle A. and Läderach P. (2019) Vulnerability of the agricultural sector to climate change: The development of a pan-tropical Climate Risk Vulnerability Assessment to inform sub-national decision $\begin{array}{llll}\text { making. PLOS ONE } & \text { 14(3): }\end{array}$ e0213641. https://doi.org/10.1371/journal.pone.0213641

Paquit, J., Bruno, A.G. and Salingay, R. (2018). Climate-risk vulnerability assessment of the agriculture sector in the municipalities and cities of Bukidnon, Philippines. 13. 146-151. 10.12692/ijb/13.6.155-168.

Perez, M.L. and Sajise, A.U. (2013) Economic Analysis of Climate Change Adaptation Strategies in Selected Coastal Areas in Indonesia, Philippines and Vietnam. WordFish, Penang, Malaysia. https://www.worldfishcenter.org/content/economic-analysisclimate-change-adapta tion-strategies-selected-coastal-areasindonesia-0

Scandurra G., A.A. Romano, M. Ronghi, A. Carfora (2018) On the vulnerability of Small Island Developing States: A dynamic analysis 84 ,

https://doi.org/10.1016/j.ecolind.2017.09.016
$382-392$. 